\title{
Overview of the Pattern of Complementary Feeding to Stunting Toddlers Age 6-24 Months in the Tampo Banyuwangi Community Health Center Work Area
}

\author{
Farihatuz Zakiyah $^{1}$, Ahmad Suryawan ${ }^{2}$, Widati Fatmaningrum ${ }^{3}$ \\ ${ }^{1}$ School of Midwifery, Faculty of Medicine Universitas Airlangga 60132, Surabaya, East Java, Indonesia \\ ${ }^{2}$ Departemen of Child Health, Faculty of Medicine Universitas Airlangga 60132, Surabay, East Java, Indonesia \\ ${ }^{3}$ Department of Public Health Sciences Preventive Medicine, Faculty of Medicine Universitas Airlangga 60132, Surabaya, East Java, Indonesia \\ ${ }^{2}$ suryawan.ahmad@gmail.com
}

\begin{abstract}
Background: Stunting is short body age less than -2SD measured using Z-score, which is influenced by the nutritional status of children. Stunting is a national health problem that is the main target of health development. The provision of complementary feeding is related to stunting status in toddlers. This study aims to determine the description of the pattern of giving complementary feeding to stunting toddlers aged 6-24 months. Methods: This study uses a descriptive type of research, namely research conducted to describe or describe a phenomenon in society. The number of samples, as many as 20 respondents and sampling using total sampling. The data used are primary and secondary data obtained from questionnaires, KIA book notes and food recall. Data analysis used univariate analysis. Results: The results showed that the intake of energy, protein, carbohydrates, fat, and stunting in toddlers was less than the nutritional adequacy rate (RDA) according to age. The first time complementary feeding given, the results were 55\% incorrect at the age of 6 months, 5\% complementary feeding given early and 50\% was given at the age of more than 6 months. Conclusion: The resulting data illustrates the pattern of inadequate complementary feeding as seen from the intake of energy, protein, carbohydrates, fat, and fiber less than the nutritional adequacy rate (RDA) according to age.
\end{abstract}

Keywords: stunting; complementary feeding; AKG

\section{Introduction}

Stunting defined as nutritional status which is calculated based on the index of body length for age or height for age, which is seen according to a Z-score of less than -2SD (standard deviation) in toddlers aged 0-59 months [1]. Stunting is one of the national priorities where the government committed to reducing the prevalence of stunting, so it must be monitored every year (2). The prevalence of stunting or stunting in Indonesia is still high, so this is a health problem that must be addressed [3]. Severe nutritional issues causes by high stunting rates in children under five, which has an impact on the quality of Human Resources [4]. 
According to the WHO World Health Organization, Indonesia is the highest prevalence in Southeast Asia / Southeast Asia Regional (SEAR) where Indonesia is the third country with stunting toddlers [5]. According to the 2018 Basic Health Research by Balitbangkes, the prevalence of stunting in Indonesia is 30.8\%, which is high because it exceeds the cut-off point set by WHO. Meanwhile, East Java has a stunting prevalence of $32.8 \%$, where the prevalence is higher than the prevalence in Indonesia. The results of the 2019 Integrated Toddler Nutritional Status Study stated that the prevalence of stunting in Indonesia was $27.67 \%$. This shows that the prevalence of stunting in Indonesia has decreased compared to the previous year, but is still above the threshold set by WHO [6]. The prevalence of stunting in East Java is $26.7 \%$ of children under five suffering from stunting. The stunting rate in Banyuwangi Regency found $26.2 \%$ of children under five who suffer from stunting. [3]. Based on data from the Tampo Health Center in February 2020, the prevalence of stunting reached $29.4 \%$ or there were 340 stunted toddlers out of a total of 1155 toddlers who took part in the weighing month.

The incidence of stunting has short-term and long-term impacts. Short-term impacts include increased mortality and morbidity, decreased cognitive development or intelligence, motor skills, language, and increased health care costs. Long-term impacts include short stature, increased risk of obesity and its comorbidities, decreased reproductive health, learning achievement and capacity, and work ability and capacity [7]. Therefore, the main target of health development in the 2020-2024 RPJMN is to support nutrition improvement, namely to reduce the prevalence of stunting and wasting in toddlers [1]. One of the factors causing stunting is the provision of inadequate supplementary food including complementary feeding which consists of types of food according to age, frequency of administration and also the amount of food consumed, as well as food consistency. Complementary feeding given together with breast milk from 6 months to 2 years not to replace breast milk, but to complement breast milk. Delay in giving complementary feeding can cause growth delay due to lack of iron intake and can lead to stunting [7]. While giving complementary feeding too early with the age of less than 6 months increases the risk of infections such as diarrhea because the complementary feeding given is not as clean and as easy as breast milk when digested [8]. According to research [9], it stated that the provision of complementary feeding associated with stunting status in toddlers. This is also in line with research that reported that the status of complementary feeding with protein intake associated with stunting in children [10][11].

\section{Method}

The study used a descriptive method using primary data and secondary data in the form of notes in the MCH book. The research implemented in the Tampo Banyuwangi Public Health Center Work Area. The population in this study were mothers who had children aged 6-24 months in the Tampo Banyuwangi Health Center Work Area. The sample in this study amounted to 20 people who were taken by the total sampling method. Data on complementary feeding measured using a questionnaire and food recall adopted from previous studies.

\section{Result}

This research implemented in the Tampo Banyuwangi Indonesia Health Center Work Area. There sample are 20 of mothers who have children aged 6-24 months. 
Table 1 Characteristics of Mothers and Toddlers

\begin{tabular}{lll}
\hline Variable & Amount (n) & Percentage (\%) \\
\hline Mother's Age & 4 & 20 \\
$\quad<20$ & 14 & 70 \\
$20-35$ & 2 & 10 \\
$>35$ & & \\
Mother's Education & 3 & 15 \\
$\quad$ Primary school & 9 & 45 \\
Middle school & 6 & 30 \\
High school & 2 & 10 \\
College & & \\
Mother's Job & 5 & 25 \\
Farmer & 2 & 10 \\
Enterpreneur & 2 & 10 \\
Teacher & 11 & 55 \\
Not working & & \\
Toddler gender & 7 & 35 \\
Male & 13 & 65 \\
Female & & \\
Toddler age & 5 & 25 \\
6-11 & 15 & 75 \\
12-24 & &
\end{tabular}

Based on table 1 shows that the majority of mothers have a vulnerable age of 20-35 years, as much as $70 \%$. The most recent educational history of mothers is junior high school level by $45 \%$ and most mothers do not work or become housewives with a percentage of 55\%. Most of the children under five are female by $65 \%$ and most are dominated by the age range of $12-24$ months as much as $75 \%$.

Table 2 history of early initiation of breastfeeding, history of exclusive breastfeeding and history of complementary foods

\begin{tabular}{lll}
\hline Variable & Amount (n) & Percentage (\%) \\
\hline Early breastfeeding initiation & 12 & 60 \\
$\quad$ Yes & 8 & 40 \\
$\quad$ No & & \\
Exclusive breastfeeding & 12 & 60 \\
$\quad$ Yes & 8 & 40 \\
$\quad$ No & & \\
Complementary feeding & 9 & 45 \\
$\quad$ Yes & 11 & 55 \\
No & &
\end{tabular}

Based on table 2, the distribution of BMI history found to be more than $60 \%$ of mothers who had IMD. The history of exclusive breastfeeding was dominated by mothers who did exclusive breastfeeding by $60 \%$. As for the history of complementary feeding, the most that was not appropriate was $55 \%$.

Table 3 Nutrient intake consisting of energy, protein, carbohydrates, fat, and fiber 


\begin{tabular}{llll}
\hline Variabel & Average & Minimal & Maximum \\
\hline Age 6-11 months & & & \\
Energy Intake (kcal) & 761.4 & 536 & 975 \\
Protein Intake (g) & 19.21 & 15.34 & 281 \\
Carbohydrate Intake (g) & 106.69 & 66.79 & 170,87 \\
Fat Intake (g) & 29.46 & 23,77 & 36,64 \\
$\quad$ Fiber Intake (g) & 2.82 & 1,7 & 3,7 \\
Age 12-24 months & & & \\
Energy Intake (kcal) & 980,2 & 653 & 1500 \\
Protein Intake (g) & 36,2 & 10,87 & 70,46 \\
Carbohydrate Intake (g) & 93 & 93 & 211,76 \\
Fat Intake (g) & 37,11 & 26,85 & 56,93 \\
Fiber Intake (g) & 3,25 & 1,3 & 6,4 \\
& & & \\
& & & \\
\hline
\end{tabular}

Based on table 3, the results show that the average energy intake for toddlers aged 6-11 months is 761.4 $\mathrm{kcal} / \mathrm{day}$. The average protein intake is $19.21 \mathrm{~g} /$ day. The average carbohydrate intake is $106.69 \mathrm{~g} /$ day. The average fat intake is $29.46 \mathrm{~g} /$ day. The average fiber intake is $2.82 \mathrm{~g} / \mathrm{day}$. In toddlers aged 12-24 months, the average energy intake is $980,2 \mathrm{kcal} / \mathrm{day}$. The average protein intake is $36.2 \mathrm{~g} / \mathrm{day}$. The average carbohydrate intake is $93 \mathrm{~g} / \mathrm{day}$. The average fat intake is $37.11 \mathrm{~g} /$ day. The average fiber intake is $3.25 \mathrm{~g} / \mathrm{day}$.

\section{Discussion}

Maternal age during pregnancy is one of the factors that have an influence on children born short, therefore the age of the mother during pregnancy needs to be considered. At the age of the mother <20 years, there will be competition for nutritional fulfillment between the mother and the developing fetus, so that the nutritional needs needed are more than those of the mother aged 20-35 years [12]. Mothers aged $<20$ years and $>35$ years have a higher risk of giving birth to children with stunting status which can give birth to low birth weight, premature birth, infant mortality, intrauterine growth disorders and poor child growth [12] [13]. The average respondent in this study was mothers of stunted toddlers who were aged 20-35 years when that age was a good reproductive age for pregnancy [13]. The condition of the mother before pregnancy is one of the factors that cause stunting in terms of weight, height, and nutrition.

The mother's last education has an impact on the occurrence of stunting in children, especially at low levels of education because the lower the education level of the mother, the higher the risk of stunting in children [14][15]. Mother's education level affects health status because good nutritional knowledge will play a role in determining child growth and development because the mother's role cannot be separated from children's eating habits from shopping, cooking, and preparing food [16][17]. The mother's last education has a big role in the incidence of stunting in children. Where the higher the education of the mother, the higher the knowledge that can be obtained by the mother.

Mother's occupation is one of the factors in the incidence of stunting in children. Work affects knowledge, where someone who works has broad knowledge compared to someone who does not work, and work status greatly determines behavior in children's nutritional intake [18]. Mother's employment status can impact the occurrence of 
stunting because working mothers will have more knowledge about nutrition because their social environment is wider than mothers who do not work.

According to research, female gender has a risk of being stunted [19][20]. The incidence of malnutrition is more common in girls than boys, according to research [21]. But according to Amelia's research, 2020 boys who have a male gender have twice the risk of being stunted compared to female babies at the age of 6 and 12 months. According to Rahayu's 2020 research, there is no difference in growth in toddlers, and therefore gender is not relate with stunting[22]. Gender differences are a risk factor for stunting due to differences in the eating practices given by parents to children and differences in children's activities.

Low-energy intake contributes to the high factors that cause stunting because total energy has a direct relationship with the occurrence of physical growth deficits in children. Low-energy intake is related to maternal ignorance about stunting, and mothers do not pay attention to energy intake in children because they think that children do not have problems. Energy intake is an indicator for assessing food consumption in children [23][24]. Children with low levels of energy adequacy have a 3.09 times greater risk of becoming stunted compared to children who have good energy adequacy levels [24]. In this study, the results showed that the average energy intake of toddlers was still not in accordance with the nutritional needs.

Protein is a form of new tissue in the growth and development of children, maintains, repairs and replaces damaged tissue. Lack of protein intake will inhibit growth, even adequate energy intake [25][26][27]. It can be concluded that protein intake has a relationship with the incidence of stunting, and a lack of protein intake will have a 13.77 times greater risk of stunting than children with good protein intake [28]. However, according to a study conducted by Widiastuti, it was stated that there was no relationship between protein intake and the incidence of stunting because toddlers in the working area of the Soropia Public Health Center were dominated by adequate protein intake [29].

Carbohydrates are the main source of energy for activities and are needed by humans. Excess carbohydrate intake will be stored in the form of fat for energy reserves [30]. According to Sulistianingsih's research, in 2016 the number of adequacy of carbohydrate intake is lacking for stunting toddlers. Low carbohydrate intake will cause 1.7 times more children to experience stunting [31][32]. Carbohydrate intake is one of the energy intakes required by toddlers to carry out daily activities. Low carbohydrate intake will affect growth and development in toddlers.

Low-fat intake in toddlers can increase the risk of stunting 1.31 times compared to toddlers with adequate fat intake levels [33]. Fat is the highest energy producer compared to protein and carbohydrates. Energy imbalance caused by unmet energy intake. Energy imbalance in the long term will cause nutritional problems that impact brain function and development and result in stunted growth and development. Carbohydrates, proteins, and fats are macronutrients that function to support growth, metabolism and play a role in the process of physical activity [34]. Fiber is a food composition that cannot be digested by enzymes in the human body. Low and excessive fiber intake can have a negative impact on the body [35]. Food imbalances consisting of sources of carbohydrates, proteins, fats, vitamins, and minerals as well as sources of fiber can lead to malnutrition and stunting. Food imbalances can be seen from the variety of inappropriate intake compositions [36]. 


\section{Kesimpulan}

Based on research on mothers with stunted toddlers aged 6-24 months in the Tampo Health Center Work Area, found that the pattern of giving complementary feeding seen from the intake of energy, protein, carbohydrates, fat, and fiber is not in accordance with the nutritional adequacy rate for toddlers. About the quantity of food consumed, there is less variety as evidenced by the intake of energy, protein, carbohydrates, fat, and fiber whose value is less than the nutritional adequacy rate. The provision of complementary feeding considers inadequate because it was given too early and given more than 6 months of age.

\section{Acknowledgements}

The researcher would to thank the supervisor who had guided in this research and puskesmas Tampo who has permitted me to conduct research.

\section{References}

[1] Kementrian Kesehatan RI, -Indikator Program Kesehatan Masyarakat Dalam Rpjmn Dan Renstra Kementerian Kesehatan Tahun 2020-2024,\| Kemenkes RI, 2020.

[2] K. Kesehatan, -Laporan Kinerja Kementrian Kesehatan Tahun 2020, l 2020.

[3] Kementerian Kesehatan RI, —Buku saku pemantauan status gizi,\| Buku saku pemantauan status gizi tahun 2017, pp. 7-11, 2018.

[4] E. putro Sandjojo, -Buku saku desa dalam penanganan stunting,\| Buku Saku Desa Dalam Penanganan Stunting, p. 42, 2017.

[5] Kemenkes RI, -Buletin Stunting,॥ Kementeri. Kesehat. RI, vol. 301, no. 5, pp. 1163-1178, 2018.

[6] D. Izwardy, -Studi Status Gizi Balita,\| Balitbangkes Kemenkes RI, no. 2020, p. 40, 2020.

[7] WHO, - Childhood Stunting: Context, Causes and Consequences WHO Conceptual Framework, $\|$ Who, vol. 9, no. 2, pp. 27-45, 2013.

[8] A. Nugroho, -Determinan Growth Failure (Stunting) pada Anak Umur 1 S/D 3 Tahun (Studi di Kecamatan Tanjungkarang Barat Kota Bandar Lampung),\| J. Kesehat., vol. 7, no. 3, p. 470, 2016, doi: 10.26630/jk.v7i3.231.

[9] Nur Hadibah Hanum, -Hubungan Tinggi Badan Ibu dan Riwayat Pemberian MP-ASI dengan Kejadian Stunting pada Balita Usia 24-59 Bulan,\| Amerta Nutr., vol. 3, no. 2, pp. 78-84, 2019, doi: 10.2473/amnt.v3i2.2019.78-84.

[10] H. Haryani, Y. S. Pratiwi, K. Rusmil, M. Dhamayanti, and F. Husin, -Hubungan Status Pemberian Asi Dan Makanan Pendamping Asi Terhadap Stunting Anak Usia 1-2 Tahun Di Kecamatan Cisolok Kabupaten Sukabumi Tahun 2015,॥ J. Gizi Klin. Indones., vol. 53, no. 9, pp. 55-69, 2019.

[11] H. Mizobe et al., -Structures and Binary Mixing Characteristics of Enantiomers of 1-Oleoyl-2,3dipalmitoyl-sn-glycerol (S-OPP) and 1,2-Dipalmitoyl-3-oleoyl-sn- glycerol (R-PPO),॥ JAOCS, J. Am. Oil Chem. Soc., vol. 90, no. 12, pp. 1809-1817, 2013, doi: 10.1007/s11746-013-2339-4.

[12] A. Wemakor, H. Garti, T. Azongo, H. Garti, and A. Atosona, -Young maternal age is a risk factor for child undernutrition in Tamale Metropolis, Ghana,॥ BMC Res. Notes, vol. 11, no. 1, pp. 1-5, 2018, doi: 10.1186/s13104-018-3980-7.

[13] A. Karabulut, S. Ozkan, A. I. Bozkurt, T. Karahan, and S. Kayan, -Perinatal outcomes and risk factors in adolescent and advanced age pregnancies: Comparison with normal reproductive age women,॥ J. Obstet. Gynaecol. (Lahore), vol. 33, no. 4, pp. 346-350, 2013, doi: 10.3109/01443615.2013.767786.

[14] A. D. Laksono and H. Megatsari, -Determinan Balita Stunting di Jawa Timur: Analisis Data Pemantauan Status Gizi 2017,॥ Amerta Nutr., vol. 4, no. 2, p. 109, 2020, doi: 10.20473/amnt.v4i2.2020.109-115.

[15] I. Picauly and S. M. Toy, -Analisis Determinan Dan Pengaruh Stunting Terhadap Prestasi Belajar Anak Sekolah Di Kupang Dan Sumba Timur, Ntt,l J. Gizi dan Pangan, vol. 8, no. 1, p. 55, 2013, doi: 10.25182/jgp.2013.8.1.55-62.

[16] A. Rahayu and L. Khairiyati, —Risiko Pendidikan Ibu Terhadap Kejadian Stunting Pada Anak 6-23 Bulan,\| Penelit. Gizi dan Makanan (The J. Nutr. Food Res., vol. 37, no. 2 Dec, pp. 129-136, 2014, [Online]. 
Available: http://ejournal.litbang.depkes.go.id/index.php/pgm/article/view/4016.

[17] S. Dahlia, -Peningkatan Status Gizi Balita the Effect of Positive Deviance Approach Toward the Improvement of Nutrition Status of Children Under Five Years,॥ Media Gizi Masy. Indones., vol. 2, no. 1, pp. $1-5,2012$.

[18] F. Amelia, -Hubungan Pekerjaan Ibu, Jenis Kelamin, dan Pemberian Asi Eklusif Terhadap Kejadian Stunting Pada Balita 6-59 Bulan di Bangka Selatan,\| J. Kesehat. Poltekkes Kemenkes Ri Pangkalpinang, vol. 8, no. 1, p. 1, 2020, doi: 10.32922/jkp.v8i1.92.

[19] K. R. Illahi and Zki, -Hubungan_Pendapatan_Keluarga_Berat_Lahir_Dan_Panja,॥l Manaj. Kesehat., vol. 3, no. 1, pp. 1-14, 2017.

[20] E. Ayensu and S. Darkwa, - An Assessment of the Nutritional Status of under Five Children in Four Districts in the Central Region of Ghana,ll Asian J. Agric. Rural Dev., vol. 3, no. 11, pp. 851-860, 2013, [Online]. Available: http://www.eajournals.org/wp-content/uploads/Assessment-and-Determinants-of-NutritionalStatus-in-a-Sample-of-Under-Five-Year-Old-Iraqi-Children.pdf.

[21] B. C. Rosha, Hardinsyah, and Y. F. Baliwati, -Analisis Determinan Stunting Anak 0-23 Bulan pada Daerah Miskin di Jawa Tengah dan Jawa Timur,\| J. Nutr. Food Res., vol. 35, no. 1, pp. 34-41, 2012, [Online]. Available: https://media.neliti.com/media/publications/223475-none.pdf.

[22] P. P. Rahayu and Casnuri, -Perbedaan Risiko Stunting Berdasarkan, Il pp. 135-139, 2020.

[23] S. Mugianti, A. Mulyadi, A. K. Anam, and Z. L. Najah, -Faktor Penyebab Anak Stunting Usia 25-60 Bulan di Kecamatan Sukorejo Kota Blitar,\| J. Ners dan Kebidanan (Journal Ners Midwifery), vol. 5, no. 3, pp. 268-278, 2018, doi: 10.26699/jnk.v5i3.art.p268-278.

[24] W. Lestari, A. Margawati, and Z. Rahfiludin, -Faktor risiko stunting pada anak umur 6-24 bulan di kecamatan Penanggalan kota Subulussalam provinsi Aceh,\| J. Gizi Indones. (The Indones. J. Nutr., vol. 3, no. 1, pp. 37-45, 2014, doi: 10.14710/jgi.3.1.126-134.

[25] E. Ekweagwu, A. E. Agwu, and E. Madukwe, -The role of micronutrients in child health: A review of the literature,\| African J. Biotechnol., vol. 7, no. 21, pp. 3804-3810, 2008, doi: 10.4314/ajb.v7i21.59444.

[26] I. A. Ibrahim and R. Faramita, -Hubungan faktor sosial ekonomi keluarga dengan kejadian stunting anak usia 24-59 bulan di wilayah kerja puskesmas Barombong kota Makassar tahun 2014,॥ Al-Sihah Public Heal. Sci. J., vol. 7, no. 1, pp. 63-75, 2015, [Online]. Available: http://103.55.216.55/index.php/AlSihah/article/view/1978.

[27] E. Sundari and Nuryanto, -Hubungan Asupan protein, Seng, Zat Besi dan Riwayat Penyakit Infeksi dengan Z-Score TB/U Pada Balita,\| J. Nutr. Coll., vol. 5, no. no 4, pp. 521-529, 2016, doi: 10.1038/184156a0.

[28] R. C. Mirna Kawulusan, Rivolta G. M Walalangi Jufri Sineke1, -Pola Asuh dan Pola Makan Sebagai Faktor Risiko Stunting Balita Usia 6-24 Bulan Suku Papua dan non- Papua,ll Home Econ., vol. 35, no. 5, pp. 175183, 2019.

[29] W. Widiastity, -Hubungan Pemberian MP-ASI Terhadap Kejadian Stunting Pada Balita Usia 6 - 24 Bulan di Puskesmas Soropia,\| Nurs. Care Heal. Technol., 2020.

[30] S. K. M. Merryana Adriani, Peranan gizi dalam siklus kehidupan. Prenada Media, 2016.

[31] D. A. M. Y. Apri Sulistianingsih, -Kurangnya Asupan Makan Sebagai Penyebab Kejadian Balita Pendek ( Stunting ),l J. Dunia Kesehat., vol. 5, no. 1, pp. 71-75, 2016.

[32] U. Azmy and L. Mundiastuti, -Konsumsi Zat Gizi pada Balita Stunting dan Non- Stunting di Kabupaten Bangkalan Nutrients Consumption of Stunted and Non-Stunted Children in Bangkalan,\| Amerta Nutr., pp. 292-298, 2018, doi: 10.20473/amnt.v2.i3.2018.292-298.

[33] Z. Oktarina and T. Sudiarti, -Faktor Risiko Stunting Pada Balita (24-59 Bulan) Di Sumatera,\| J. Gizi dan Pangan, vol. 8, no. 3, p. 177, 2014, doi: 10.25182/jgp.2013.8.3.177-180.

[34] A. Ayuningtyas, D. Simbolon, and A. Rizal, -Asupan Zat Gizi Makro dan Mikro terhadap Kejadian Stunting pada Balita,\| J. Kesehat., vol. 9, no. 3, p. 445, 2018, doi: 10.26630/jk.v9i3.960.

[35] E. M. Ambarita, S. Madanijah, and D. G. Masyarakat, -Hubungan Asupan Serat Makanan Dan Air Dengan Pola Defekasi Anak Sekolah Dasar Di Kota Bogor,॥ J. Gizi dan Pangan, vol. 9, no. 1, pp. 7-14, 2014, doi: 10.25182/jgp.2014.9.1.

[36] Indrastuti, A. P. Sari, and Nuraliah, -Karakteristik Keluarga dan Pola Konsumsi Pangan Balita di Wilayah Locus Stunting Kecamatan Balanipa Kabupaten Polewali Mandar,\| J. Borneo Holist. Heal., vol. 3, no. 2, pp. 151-158, 2020, [Online]. Available: http://jurnal.borneo.ac.id/index.php/borticalth/article/view/1691. 
